Andrews University

Digital Commons @ Andrews University

Honors Theses

Undergraduate Research

4-5-2019

\title{
The Restoration of God's Character in Physical Disabilities
}

Delaneira Kuntoria

Andrews University, delaneira@andrews.edu

Follow this and additional works at: https://digitalcommons.andrews.edu/honors

Part of the Religion Commons

\section{Recommended Citation}

Kuntoria, Delaneira, "The Restoration of God's Character in Physical Disabilities" (2019). Honors Theses.

211.

https://dx.doi.org/10.32597/honors/211

https://digitalcommons.andrews.edu/honors/211

This Honors Thesis is brought to you for free and open access by the Undergraduate Research at Digital Commons @ Andrews University. It has been accepted for inclusion in Honors Theses by an authorized administrator of Digital Commons @ Andrews University. For more information, please contact repository@andrews.edu. 


\title{
J. N. Andrews Honors Program \\ Andrews University
}

HONS 497

Honors Thesis

The Restoration of God's Character in Physical Disabilities

\author{
Delaneira Kuntoria
}

5 April 2019

Advisor: Rodney Palmer, D.Min.

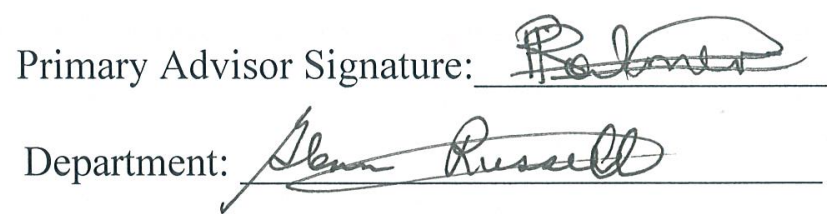

Department of Religion and Biblical Languages 


\section{THE RESTORATION OF GOD'S CHARACTER IN PHYSICAL DISABILITIES}

\section{Introduction}

\section{A Substantial Minority}

The government estimated standing of persons with disabilities in the United States in 2008 came to a substantial 54.4 million, with numbers climbing as high as 56.7 million by $2010 .^{1}$ This means that nearly one out of every five US citizen in 2010 was affected by an impairing condition, which more than fifty percent of research participants classified as severe. ${ }^{2}$ These glaring figures reveal that people with disabilities are clearly a prevalent minority "other" within the American social structure. However, despite the evident need for effective disability ministries in reaching out to this massive subgroup, the urgency to refine these efforts are not always palpable to the general congregation. This is perhaps due to the various attitudes that are held towards those who experience incapacitating maladies that make them appear less than "normal." ${ }^{3}$ The spectrum of opinions regarding disabled members of the church includes various conclusions such as the rationalization of disabilities as a more perfect reflection of the un-whole human condition, ${ }^{4}$ and more stringent outlooks that adhere to Thomas Aquinas' strong punishment argument. People who subscribe to the strong punishment view maintain that disabilities denote a punitive measure towards $\sin ^{5}$ Nevertheless, the former is problematic as it implies that people with disabilities are "un-whole" beings, while the latter presents conflicts

\footnotetext{
${ }^{1}$ The statistics for 2008 can be found in the medical social work course textbook. Meredith E. Drench et al., Psychosocial Aspects of Health Care, 3rd ed. (Upper Saddle River, NJ, NJ: Pearson, 2012), 223. The statistics for 2010 can be found in the United States Census Bureau website. US Census Bureau Public Information Office, "Nearly 1 in 5 People Have a Disability in the U.S., Census Bureau Reports," U.S. Census Bureau, May 19, 2016, accessed February 12, 2019, https://www.census.gov/newsroom/releases/archives/miscellaneous/cb12-134.html.

2 Ibid.

${ }^{3}$ Meredith E. Drench et al., Psychosocial Aspects of Health Care, 3rd ed. (Upper Saddle River, NJ, NJ: Pearson, 2012), 224.

${ }^{4}$ Tim Basselin, "Why Theology Needs Disability," Theology Today 68, no. 1 (2011): , doi:10.1177/0040573610394925.

${ }^{5}$ Cross, Richard. "Duns Scotus on Disability: Teleology, Divine Willing, and Pure Nature." Theological Studies 78, no. 1 (2017): 72-95. doi:10.1177/0040563916682324.
} 
with God's compassionate character in light of using human infirmities as a tool for punishing transgressions.

The Problem with Disabilities and Divine Love

Another explanation for disabilities in the Bible, is that God allows it to occur so that the biblical characters can learn to more ardently trust and depend upon the Father's guidance and care. ${ }^{6}$ This view is congruent with the concept of John Hick's soul-making theodicy in which Hicks asserts that God allows for adverse circumstances to occur in order to refine and perfect human character. Although this argument appears sound and homiletically appealing, the defense fails to satisfy the troubling inquiry on God's tender character: How can a loving Father impose adverse physiological ailments upon His children? This question can be further embodied by a popular illustration of a shepherd and a sheep that constantly wanders away from the safety of the flock, and becomes ensnare in various precarious situations. In order to help the sheep learn to stay close to the shepherd and away from the dangers of the mountain, the shepherd resorts to breaking the sheep's leg, and carry the injured animal upon his shoulder.

Due to the fact that the sheep is constantly kept in close proximity to the shepherd while the wound heals, the idea is that through this experience the sheep will eventually learn to rely upon his caregiver and develop a more profound love for him. Overtime the sheep is able to walk again, and instead of wandering from the fold it now stays close to the shepherd. As beautiful as this narrative might seem on the surface, it exhibits elements of uncharacteristic maleficence on God's part. In response to this challenging aspect, the primary purpose of this research is to construct a theodicy that more accurately reconciles God's hesed, or loving-kindness, with His

\footnotetext{
${ }^{6}$ This justification for the presence of disabilities was the inspiration of this paper. I have heard preachers describe disabilities as a means for teaching humans how to "lean" upon God numerous times. The summarization of an individual's painful experience as a mere call to depend upon God more always put a wedge in my understanding of God's affectionate and devoted character. It is my hope to unravel a theodicy on disabilities that is able to keep God's love intact.
} 
allowance of human disabilities through the exegetical analysis of three passages: Genesis 32:2531; Acts 9:3-9, 17-19; and John 9:1-7.

Defining "Disability"

Before I continue, however, it is important to first delineate and define the term "disability," which can be broadly employed to cover areas such as physical, cognitive, and psychological infirmities. Due to the nature of this paper, the scope of the term will be limited to physical ailments since they are more readily identifiable in Scripture. Furthermore, a physical disability, according to Gloria L Schaab, is any impairment to a person's physiological system that limits their ability to take part in activities and tasks. ${ }^{7}$ In the Old Testament, Jacob walked away from his night of wrestling with a limp. In the New Testament, Paul of Tarsus was left partially blind after experiencing his first theophany, and an unnamed man was born completely blind in order to demonstrate divine providence. The conditions of these three men can be summarized as God's means for punishing them in order to draw them back to Him, but I believe that there is a deeper underlying meaning within the texts that restores God's compassion into His actions.

In addition to probing the issue of why God utilizes disabilities, this research will also aim to refine and restore human understanding of the Father's character by extracting the proper method of implementing disability ministries from the Bible. The sacred text is the Church's main source of special revelation from God, and it serves as a guide and corrector to our image of God in today's fallen world. Thus, we can uncover the Divine's attitude towards disabilities by studying His biblical provision and involvement with disabled individuals. This section of the research will also defend God's character by evaluating the implications of Scripture on the way

\footnotetext{
7 Schaab, Gloria L. "Disabling Christian Discourse the Mystery of God in the Experience of Disability," Theoforum 46, no. 2 (2015): 219-40. doi:10.2143/tf.46.2.3209417.
} 
that churches should perceive and minister to those with disabilities. As an appointed agency of God, a church defines the image of the Father's character to its surrounding community and members. Consequently, it is crucial for churches to have a proper biblical foundation for ministering to people with disabilities, so as to restore God's caring image to those experiencing difficult medical conditions.

\section{Methodology}

\section{Phase One}

I will obtain my data from the Bible by doing exegesis on three passages that involve scenes in which God directly or indirectly allows a person to have a physiological disability. Exegesis is a process that employs hermeneutical, or interpretative, tools to extract the meaning from Scripture as opposed to eisegesis, which is when a researcher imposes their own interpretation on the text. In order to prevent the leaking of personal presuppositions of the text into my research, I will begin with a literal, or word-for-word translation of the original Hebrew and Greek manuscripts. I will demonstrate my methodology with the example of Jacob's wrestling account as illustrated in Genesis 32:25-31. A literal translation of the Hebrew text requires the parsing of each word. Parsing is the breaking down of a single verb, noun, article, or adjective into different elements. For verbs and adverb, I will break down each word into five parts: verb stem (Qal, Niphal, Piel, Pual, Hophal, Hiphil, Hithpael), tense (perfect, imperfect, imperative, infinitive, participle), person (third, second, first), gender (masculine, feminine), and number (singular, plural). For nouns and articles, I will break each word down into two parts: gender (masculine, feminine) and number (singular, plural). For adjectives, I will break down each word into three parts: person (third, second, first), gender (masculine, feminine), and number (singular, plural). Parsing the words gives grammatical context to the proper syntax of 
each verse, which is essential in the drafting of a smooth translation. So as to eliminate all personal theological bias, when translating the passage, I will endeavor to be as objective as possible. However, the process will require the employment of personal theology for phrases that have multiple possible meanings; this is especially true for Hebrew due to its fluidity.

After writing the smooth translation of the passage, 5-10 words that are significant to the meaning of the text will be studied in greater detail. Since focus will be placed on God and disabilities, a word study will be done on the etymology of verbs and nouns such as "touch" and "hip." A word study involves looking at its root form, and doing an intertextual comparison throughout the entire Bible. Intertextuality is the application and evaluation of concepts by using passages from different parts of the Bible. Herein, the Septuagint version will be utilized to compare the Old Testament and New Testament writings. The Septuagint is the translation of the Old Testament from Hebrew to Greek, and the translation of the New Testament from Greek to Hebrew. Through this method, I am able to identify the usage of Hebrew words in the New Testament. Next, I will investigate into the Sitz im Leben, or "setting in life," of the pericope in order to get a clearer picture of how the passage relates to the Bible as a whole, such as looking into the different geographical areas mentioned. After applying the steps above to the other passages on disabilities, focus will then shift to the development of a theodicy for disability ministry. Such a defense will assist people in obtaining a better understanding of the character of God in the midst of physical disabilities, and how to better incorporate these principles into practical ministry.

\section{Results}

Specificity of the Disability 


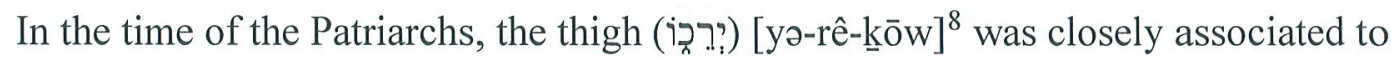
manhood, and the foundation upon which a person orients their life. ${ }^{9}$ Jud 3:16 mentions how Ehud "girded his sword on his right thigh (י,:?7): [yarek]." Eph 6:14 mentioned that the first step of

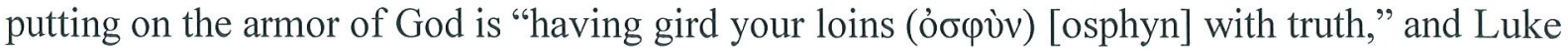

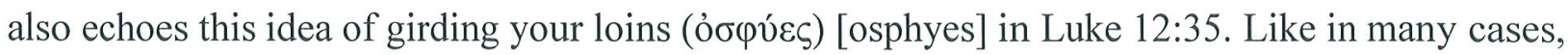

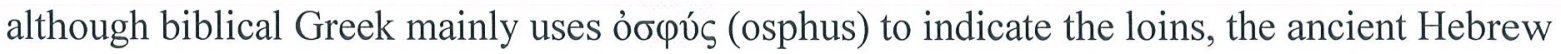
texts include several words to mean the same thing including יתר? י [yarek]. ${ }^{10}$ Therefore, since the

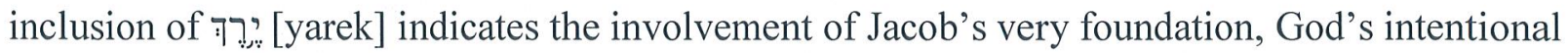
touch and displacement of Jacob's thigh further signifies a shift in Jacob's identity and personhood. This was necessary in order to correct Jacob's outlook of God's presence in his life. This concept will be further developed in a later section.

During biblical Greek times, $̌ \beta \lambda \varepsilon \pi \varepsilon v^{11}$ [eblepen] signified a stronger emphasis on the function of the eye than ópó $\omega$ [horaó] and $\theta \varepsilon \omega \rho \varepsilon ́ \omega$ [theóreó], but the three verbs can still be used interchangeably. What is more interesting, however, is the fact that the author, Saul, never uses the verb $\tau v \varphi \lambda$ ós [tuphlos] to express blindness even though that it the most literal verb for denoting physical or mental blindness. ${ }^{12}$ Instead, the apostle uses the phrase oủ $\delta \dot{\varepsilon} v$ है $\beta \lambda \varepsilon \pi \varepsilon v$ [ouden eblepen] in verse 8, which roughly reads as, "nothing he could see." The emphasis is constantly being placed on Saul's inability to see "although having opened his eyes." As a result, it is safe to conclude that the intention of the disability is not merely to impose the inability to

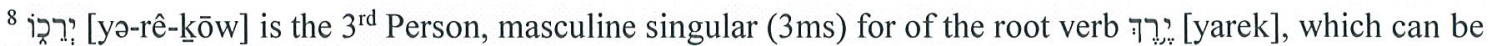
used to refer to the thigh, loin, or waist.

${ }^{9}$ Harris, R. Laird, ed. Theological Wordbook of the Old Testament. 2 vols. Chicago: Moody, c1981. (Sem. Ref. BS440 .T49)

10 "Topical Bible: Loins." Ephesians 5:5 For of This You Can Be Sure: No Immoral, Impure or Greedy Person--such a Person Is an Idolater--has Any Inheritance in the Kingdom of Christ and of God. Accessed May 4 , 2018. http://biblehub.com/topical/l/loins.htm.

${ }^{11}$ Acts 9:8. This verb denotes the act of seeing, as well as the other two mentioned after it.

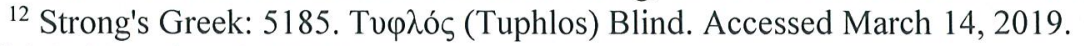
https://biblehub.com/greek/5185.htm.
} 
see, but rather to imply that the Hellenistic Jew sought to serve God without truly knowing Him. Saul earnestly believed that he was living out God's commandments when he charged towards Damascus with the letter to capture every follower of Christ, but it was clearly not God's calling.

Saul was spiritually blind despite having functioning physical eyes, and this heart condition was later embodied by the loss of his physiological functions in verse 8 . The experience of being physically blind influenced Saul to then cling to his other senses in order to survive his trip. The acts of hearing and listening to God's true voice remedied Saul's spiritual blindness by striping away the lies that the Pharisee considered as truth-lies such as the gospel of Jesus' followers being erroneous. After Ananias laid his hands on the Benjamite, the church father recovered his physical sight through the sensation of scales falling from his eyes. This phenomenon also signified the recovery of Saul's spiritual sight, and his understanding of God.

Oftentimes, the combination of seeing and hearing connote the completeness of spiritual perception within the Greek manuscripts, ${ }^{13}$ but seeing was considered to be of more importance. ${ }^{14}$ There are other examples of people, who have placed physical sight before spiritual sight and faith as well; a popular example being that of the scribes and Pharisees in Matthew 12:38. ${ }^{15}$ In this case, a portion of the Pharisees asked to see Jesus perform a sign, but the Lord refused to comply. Some of the Jews were not satisfied with hearing the messianic proclamation of Christ, and they insisted on relying upon their own ocular senses. The ancient Greeks in general were "a people of the eye," as hinted by the multiple verbs that were used to cover a broad range of meanings. This is similar to the concept of the thigh's importance in the

\footnotetext{
${ }^{13}$ Ibid.

${ }^{14}$ The act of seeing and hearing "constitute the totality of sensual and spiritual perception," because they "underlie eyewitness, personal experience and individual certainty." Gerhard Kittel, Gerhard Friedrich, and Geoffrey William Bromiley, Theological Dictionary of the New Testament (Grand Rapids, MI: Eerdmans, 2006).

${ }^{15}$ Please refer to Appendix A for other examples of people who prioritized seeing over listening, as well as a summary of the significances of
} 
times of the Patriarchs, which was a significant aspect of Jacob's conversion. Consequently, it is likely that God also wanted to touch Saul in an area he would have considered as a significant part of his life-his sight.

Structure of Genesis 32:25-31

Beyond a limp, the physical change that God caused to alter Jacob's life, was meant to also help him see that he was a changed person, an external application of the internal alteration of his heart. From a place where God initiated the discussion, to a relationship in which Jacob wanted to continue the conversation on his own, the transformation of Jacob's connection with God can be visualized in the chiastic structure of Gen 32:25-31, as demonstrated by Figure 1 .

\section{Genesis 32 Chiasm}

(A) v.25 The Angel/God sees Jacob's intention to continue, and He also sees Jacob's sin and guilt. God then transforms the very basis of Jacob's life and foundation

(B) vv.25-26 God continues to wrestle with Jacob and tests Jacob's endurance.

(C) v.26 Jacob refuses to let go until he is sure he is blessed

(D) v.27 God asks what Jacob's name and does not immediately respond with a yes or no.

(E) v.28 God knows his name, but to show that transformation that Jacob has already received, God gives Jacob a new name and directly reveals to Jacob that he has prevailed (Jacob means someone who is displaced (supplanter); Israel means someone who contends with God)

(D') v.29 Jacob asks God what His name is

(C') v.29 God refuses to reveal his name and responds with a question, the Lord blesses Jacob

(B') v.30 Jacob affirms his prevailing before God, and names the place Peniel because he has seen God face to face and was preserved

$\left(\mathrm{A}^{\prime}\right)$ v.31 Jacob's limp reminds him of his converging experience for the rest of his life. He comes out of it rejoicing in his preservation and is blessed to know that he is worthy to return.

Figure 1

The trend of "God Saw," "God continued," "Jacob refused," "God asked," indicated God's leading portion in the conversation, in which He tried to get Jacob to understand that he is still worthy to claim the entirety of God's covenant. It took Jacob another sign-the name 
change - for him to understand this. A name change was not essential for God, but he did so because Jacob would not be convinced of his prevailing before God until the Lord stated it clearly for him; thus, Israel was given, "he who contends with God" (and has prevailed).

After this outward declaration, Jacob continued the conversation by asking for God's name even though he already knew who he was, and the pattern switched to "Jacob asked", "God refused," "Jacob Affirmed," and "Jacob limp reminded." Now that Jacob is convinced of his worth, and affirmed in his repentance, he became more willing to live an intimate life with God. Instead of a last resort after going through his own plans, God became a person whom Jacob could trust and rely on as an immanent presence in his everyday life. For a person with disabilities, this shows that God had a more reflective purpose for His interaction with Jacob, and thus, God also has a deeper dialogue in His dealings with those who have a physical disability today as well. One of the significance of the thigh was that it symbolized the underpinning of a man; therefore, by changing Jacob's thigh, God also indicated a shift in Jacobs's worldview and the foundation of faith. The thigh also signified an oath of the highest order and importance. This experience was meant to remind Jacob of his covenant with God, and to affirm Jacob's part in it. Before renewing his commitment to the covenant, though, God struck Jacob's thigh to acknowledge his deepest repentance and conversion. ${ }^{16}$ Through this process, Jacob was able to recognize God's identity, how his life has been spared despite of God's almighty potency. Structure of Acts 9:3-9, 17-19

The focal point of Paul's story is that the apostle failed to see God with open eyes. This is made evident in verse 8 by the phrase, "but he could see nothing, even having opened his eyes," as shown by the chiastic format in Figure 2.

\footnotetext{
${ }^{16}$ Not in a violent manner as the connotation of "strike" must imply.
} 


\section{Acts 9 Chiasm}

(A) v.4 And having fallen on the ground, he heard a voice.

(B) vv.4-5 "Saul, Saul, why do you persecute me?" Paul replies, "Who are you Lord?" Christ answers, "I Am Jesus, whom you are persecuting."

(C) v.6 "But rise up and enter into the city, and it will be told to you that what is necessary for you to do."

(D) v.7 The men traveling with him stood speechless. Indeed having hearing the voice but seeing no one.

(E) v.8 Saul rose up from the earth, but he could see nothing, even having opened his eyes.

(D') vv.8, 15 Then leading him by the hand they brought [him] into Damascus...However the Lord said to Ananias, "Go, for this man is a vessel of choice to Me, to carry my name before the gentiles, and also kings, and the sons of Israel."

(C') v.16 "For I will show to him how much it is necessary for him to suffer for my name."

(B') vv. 17-18 "Brother Saul, the Lord, Jesus, the One who appeared to you on the road by which you were coming, has sent me, so that you might see again and be filled with the Holy Spirit."

(A') v.18 He also regained his sight. And having risen up, he was baptized.

Figure 2

The figure also exemplifies how Saul's physical bearings in versus four and eighteen reflected the steps he needed to take in order to transform his mind. In verse 4, Saul fell to the ground and heard a voice. At this point, he was unable to see due to the intensity of the light coming from heaven, and was overcome with intense apprehension. ${ }^{17}$ Ten verses later, Saul rises up after regaining his sight and is baptized. It is important to mention these instances, because the language of falling and rising is comparable to that of Jesus' death and resurrection. Years before Saul's journey to Damascus, the Son of God called out for people to take up their cross and to follow Him in Luke 9:23 (NASB). In other words, Jesus' followers were instructed to die

\footnotetext{
${ }^{17}$ Outside of the Bible, the human reflex of trepidation and angst in response to a theophany was also a common motif in ancient Greek literature. Poets such as homer often places an emphasis on the "on the fear and terrible astonishment which seize men when the deity discloses itself (Il. 1, 199; 24, 170; Od. 1, 323; 19, 36). Gerhard Kittel, Gerhard Friedrich, and Geoffrey William Bromiley, Theological Dictionary of the New Testament (Grand Rapids, MI: Eerdmans, 2006).
} 
to their old selves before being born again into a life centered upon Christ. ${ }^{18}$ Saul began the process of dying to self when he fell down, and was rendered blind. The incapacity to view truth in the way that the Pharisaical teachers taught Saul allowed him to hear the Gospel of Jesus without the dissonance of Jewish grievances. Saul was only able to focus on the voice of Jesus and His poignant rebuke, "Why are you persecuting Me? I Am Jesus."

"I Am Jesus." Ananias reaffirmed these words in verses 17-18, and they were the final weights that shifted the balance for Saul. I Am was the identity that God called Himself when He commissioned Moses in Exodus 3:14. The Hebrew phrase ['eh·yeh], or "I Am," is

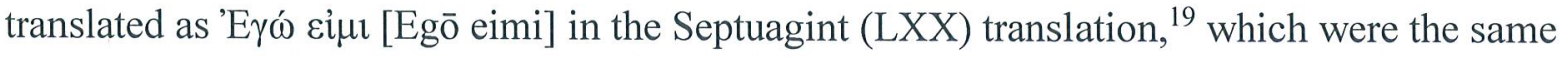
words Jesus used in Acts 9:5. Accordingly, Jesus asserted His divinity before Saul by including the words "I Am." 20 This is likely a reason why Saul does not speak again in Acts 9 until after his baptism. Saul has now shifted his attention to listening and obeying Jesus, the men traveling with him, and Ananias. The change of Saul's attitude is displayed in the Figure 2 by points C, D', and B'.

The shift in Saul's temperance eventually led to him rising up and becoming baptized. It is important to note that his baptism only came after Saul received his sight. The act of baptism was the final indication of Saul's conversion, but it was not what had changed him. Baptism by submersion water is a public proclamation of a prior baptism by the Holy Spirit. Saul's baptism by fire began the moment he fell down in point $\mathrm{A}$ of Figure 2, and was finalized the moment he rose up in point A'. Moreover, the Greek term used to denote "having risen up" came from the

\footnotetext{
${ }^{18}$ In John 3, Jesus elucidated to Nicodemus that a person must "be born again" by "water and the Spirit" in order to "enter into the kingdom of God." (NASB)

19 "Exodus 3:1 (LXX)," Blue Letter Bible, accessed March 16, 2019, https://www.blueletterbible.org/lxx/exo/3/1/s_53001.

${ }^{20}$ This connection is further strengthened by religious significances of 'E $\gamma^{\prime} \dot{\omega}$ [Egō] in the New Testament. These significances include the use of $I \mathrm{Am}$ in the self-proclamation of God, which is particularly common during a theophany. Gerhard Kittel, Gerhard Friedrich, and Geoffrey William Bromiley, Theological Dictionary of the New Testament (Grand Rapids, MI: Eerdmans, 2006).
} 


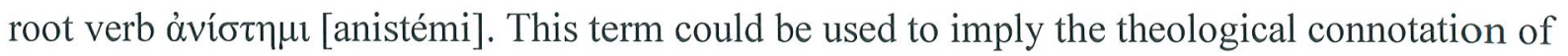
being raised form the dead, as well as signify the act of instituting someone in a function. ${ }^{21}$ Fittingly, Saul was not only being reborn, but was also being installed into his new role an apostle of Christ.

It is evident that Jesus' allowance of Saul's blindness held a more significant meaning and purpose than to simply teach the straying Paul how to depend upon the Shepherd. Thus, underestimating the deeper layers of disabilities can present problems in understanding God's intentions. It is not enough for the general public to simply sum up these experiences as the Divine's means for teaching humans how to lean on him. God's touch is specific and intentional, and meant to reach a deeper part of a person's soul. The next section of this paper dissects the meaning of God's touch even deeper.

\section{Further Significance of the Extent of God's Touch}

In Genesis 32, the Hebrew text utilizes the word y:? [way'yig ga'] to describe the way that God touches Jacob's thigh and dislocates his joint. This verb originates from the root verb

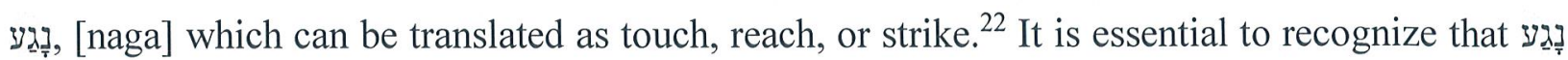
[naga] is never used to illustrate a violent strike between people, or even between God and people. ${ }^{23}$ The verb has been used to describe the tremendous and violent effects of God's touch on the earth, but never on individuals. In fact, the phrase "God touched" occurs three other times in the English translations of the Old Testament, and they illustrate how the "mountains...smoke" (Ps 104:32, Ps 144:5) and "the earth...melts" (Amos 9:5) in response to His touch. These descriptions adequately reveal how even God's smallest touch is powerful

\footnotetext{
${ }^{21}$ Ibid.

${ }^{22}$ Botterweck, G. Johannes, ed. Theological Dictionary of the Old Testament. (ongoing set) Grand Rapids: Eerdmans, 1974. (Sem. Ref. BS440 .B57 1974)

${ }^{23}$ Ibid.
} 
enough to completely unravel the world, yet here in Genesis 32, God touches a mere human being and he only experiences joint displacement.

Moreover, God could have killed Jacob from the beginning, but he chose to stay and wrestle with the mortal until sunrise. God's decision to grapple with Jacob, and the slight force of his touch implies that this was an intentional and premeditated divine action. God was not doing it to free Himself from Jacob's grip, but He did it to free Jacob from the anxiety that was gripping his very heart. Everything God did on that night was to reassure Jacob of God's faithfulness to keep His earlier promises. On his way to Haran from Beersheba, Jacob rested the night in a place named Luz and receives a dream about the ladder to heaven, and God's confirmation of His covenant that is quoted in the table below:

\begin{tabular}{|c|c|c|c|}
\hline Gen 28 & God's Promise & Jacob's Condition & $\begin{array}{l}\text { Gen } \\
28\end{array}$ \\
\hline v. 13 & $\begin{array}{l}\text { And behold, the Lord stood above } \\
\text { it and said, "I am the Lord, the } \\
\text { God of your father Abraham and } \\
\text { the God of Isaac; the land on } \\
\text { which you lie, I will give it to you } \\
\text { and to your descendants. }\end{array}$ & Then the Lord will be my God. & v. 21 \\
\hline v. 14 & $\begin{array}{l}\text { Your descendants will also be } \\
\text { like the dust of the earth, and you } \\
\text { will spread out to the west and to } \\
\text { the east and to the north and to } \\
\text { the south; and in you and in } \\
\text { your descendants shall all the } \\
\text { families of the earth be blessed. }\end{array}$ & & \\
\hline V. 15 & $\begin{array}{l}\text { Behold, I am with you and will } \\
\text { keep you wherever you go }\end{array}$ & $\begin{array}{l}\text { Then Jacob made a vow, saying, "If } \\
\text { God will be with me and will keep } \\
\text { me on this journey that I take }\end{array}$ & v. 20 \\
\hline v. 15 & $\begin{array}{l}\text { And will bring you back to this } \\
\text { land }\end{array}$ & $\begin{array}{l}\text { And I return to my father's house } \\
\text { in safety }\end{array}$ & v. 21 \\
\hline \multirow[t]{2}{*}{ v. 15} & $\begin{array}{l}\text { For I will not leave you until I } \\
\text { have done what I have promised } \\
\text { you. }\end{array}$ & & \\
\hline & & $\begin{array}{l}\text { And will give me food to eat and } \\
\text { garments to wear, }\end{array}$ & v. 20 \\
\hline
\end{tabular}


As exhibited by the table, God promised to Jacob that He would make his descendants as plentiful as the dust of the earth, and yet Jacob is largely caught up with having enough food and clothes. It is clear, that Jacob does not fully claim the depth and gravity of God's entire promise. Perhaps Jacob still felt a profound sense of guilt for his deception that he did not deem himself worthy of God's greater covenant, and thus settled for the little things. It is interesting to point out that his grandfather, Abraham, reacted to God's initial covenant in the same angst-ridden manner. In Gen 15, God promises Abram that his offspring will be as many as the stars of the heavens, and will be given a vast spectrum of land, and yet he still listens to the voice of doubt and goes about the promise in his own way after not bearing children through Sarai for a time.

Abram undermined God's provision by falling back to his own escape plan out of uncertainty, and followed the Ancient Near Eastern tradition of bearing a child through a servant. ${ }^{24}$ Jacob also undervalued God's provision by implementing his escape plan of dividing his livestock and family in case Esau overtook one of them. ${ }^{25}$ This was the root of Jacob's constant misunderstanding of God's character and, ultimately, covenant. Like Abraham, the originator, Jacob did not completely trust that God would provide, albeit their reason for believing so might stem from different experiences. Despite the numerous theories of where Jacob's fears originate from, I have decided to understand it as the result of immense selfreproach. This led Jacob to presume that God was no longer someone he could base himself upon, despite calling upon God during every moment of desperation. That is why it serves as no

\footnotetext{
${ }^{24}$ Angel, Hayyim. "Sarah's Treatment Of Hagar (Genesis 16): Morals, Messages, And Mesopotamia." Jewish Bible Quarterly41, No. 4 (2013).

Http://Jbqnew.Jewishbible.Org/Assets/Uploads/414/Jbq_414_1_Angelhagar.Pdf.

${ }^{25} \mathrm{http}$ //web.b.ebscohost.com/ehost/pdfviewer/pdfviewer?vid=0\&sid=f5f00c07-04b5-4b78-a5ad$13 \mathrm{c} 657535388 \% 40$ sessionmgr 101. "In one source (J), which I called the Survival tradition. ...Jacob divides his herd so that if Esau comes to one camp and destroys it, the other camp will escape. This source may further be distinguished in Genesis 32-33 by Jacob's sending of messengers in an attempt to find favor in [Esau's] sight and by the source's enumeration of Esau's four hundred....In contrast, in the second source (E), which I called the Gift tradition..."
} 
surprise that Jacob would fall into the same state of uncertainty and anxiety as he stood on the bank of the Jabbock River, not able to move forward and begging once again for the Lord. This is when God appears and seizes Jacob, not in a punitive or violent manner but with redemptive intentions.

In the case of Saul, Jesus could have also killed him by revealing Himself fully. When Moses prayed to see God's glory in Exodus 33:18, God agreed to his request while also warning the patriarch to hide in the cleft of a rock. The Divine took even greater measures of precaution by covering up Moses with His hand to prevent the mortal from directly seeing the full glory of the Father as He passed by to show Moses His back. God gave these special instructions so that Moses would not perish and die, for God revealed the true power of His countenance, "You cannot see My face, for no man can see Me and live!" (NASB). Indeed Jesus-being of the same nature as God-could have just as easily killed Saul by revealing the fullness of His glory, but He did not. The light from heaven only went to the extent of blinding Saul temporarily, and weakening his vision for the duration of his life. ${ }^{26}$ It could be inferred it was for this reason Jesus also covered the eyes of Saul's companion so that they were not able to see the light at all, and were then able to come out of the experience without becoming blind. The men who followed Saul were also significant since they were able to exercise their faith in bringing Saul, their Pharisaical team leader, into the city of Damascus and eventually to the hands of Ananias, a follower of the Way.

The restrained expression of God's power in light of Jacob's and Saul's disabilities underscored that disabilities are not intended to purposefully punish a person, or to even render

\footnotetext{
${ }^{26}$ Saul elucidates that the "thorn" in his flesh was a means to keep him from self- exaltation. This thorn has been interpreted as a lack of sight due to Saul's earlier blindness in Acts 9 due to understanding that Saul, also Paul, had a scribe who transcribed the Pauline letters on the apostle's behalf. Romans 16:22 reads, "I, Tertius, who write this letter, greet you in the Lord" (NASB). Additionally, Galatians 6:11 mentions that Paul wrote in big letters; this could imply that he had trouble reading little text due to a poor eyesight.
} 
them as un-whole or lacking. It was the medicine both men needed, that refocused them from their original spiritually detrimental trajectories. However, this is not to say that it is necessary for a person to be in a deteriorating state in order for God to allow disabilities. The disadvantageous conditions experienced by an individual could also be utilized to bring about the redemption and salvation of the surrounding people in that person's life.

\section{Parallel between John 9:1-7 and John 5 1:18}

The influence of a disabled individual on their environment was illustrated by the faith that was shown by the unnamed blind man in John 9, which was a corrector to the lame man in John 5. A panel comparison of the two texts will reveal the influence of their disabilities on the surrounding audience as shown by the Table 1 .

\begin{tabular}{|c|c|}
\hline John 9 & John 5 \\
\hline Man was blind from birth & Man was ill for thirty-eight years. \\
\hline $\begin{array}{l}\text { Jesus does not approach this man initially, but } \\
\text { His disciples asked Him who sinned that the } \\
\text { man was caused to be blind. }\end{array}$ & $\begin{array}{l}\text { Jesus initiates the conversation by asking the } \\
\text { man if he wants to get well. }\end{array}$ \\
\hline $\begin{array}{l}\text { Jesus answers for the man, "It was neither that } \\
\text { his man sinned, nor his parents; but it was so } \\
\text { that the works of God might be displayed in } \\
\text { him." }\end{array}$ & $\begin{array}{l}\text { Man answered, "Sir, I have no one to put me in } \\
\text { the pool." The pool was known to have } \\
\text { superstitious healing abilities to the locals; this } \\
\text { was included in verse } 4 \text {, which was added on } \\
\text { later by a scribe. }\end{array}$ \\
\hline $\begin{array}{l}\text { Jesus states, "We must work the works of } \\
\text { Him who sent Me as long as it is day; night is } \\
\text { coming when no one can work." }\end{array}$ & \\
\hline $\begin{array}{l}\text { Jesus spat on the ground, made clay, and } \\
\text { applied the mixture to the eyes of the blind } \\
\text { man. Then Jesus said, "Go and wash in the } \\
\text { pool of Siloam" (which is translated, Sent). So } \\
\text { the man went away, washed himself, } \\
\text { and came back seeing. }\end{array}$ & $\begin{array}{l}\text { Jesus said to the man, "Get up, pick up your } \\
\text { pallet and walk." Immediately the man became } \\
\text { well, and picked up his pallet and began to } \\
\text { walk." }\end{array}$ \\
\hline $\begin{array}{l}\text { People brought the man to the Pharisees, } \\
\text { because Jesus made the clay and opened his } \\
\text { eyes on the Sabbath. Then the Pharisees asked } \\
\text { the man how he received his sight. } \\
\text { And he replied, "He applied clay to my eyes, } \\
\text { and I washed, and I see." As a result, some of }\end{array}$ & $\begin{array}{l}\text { Jesus healed the man on a Sabbath, so the Jews } \\
\text { started to rebuke him by saying, "It is the } \\
\text { Sabbath, and it is not permissible for you to } \\
\text { carry your pallet." } \\
\text { And he replied, "He who made me well was the } \\
\text { one who said to me, "Pick up your pallet and }\end{array}$ \\
\hline
\end{tabular}




\begin{tabular}{|c|c|}
\hline $\begin{array}{l}\text { the Pharisees began claiming, "This man is } \\
\text { not from God, because He does not keep the } \\
\text { Sabbath." Then they asked him, "What do you } \\
\text { say about Him, since He opened your eyes?" }\end{array}$ & $\begin{array}{l}\text { walk." They asked him, "Who is the man who } \\
\text { said to you, "Pick up your pallet and walk'?" }\end{array}$ \\
\hline And he said, "He is a prophet." & $\begin{array}{l}\text { But the man who was healed did not know who } \\
\text { it was, for Jesus had slipped away while there } \\
\text { was a crowd in that place. }\end{array}$ \\
\hline & $\begin{array}{l}\text { Afterward Jesus found him in the temple and } \\
\text { said to him, "Behold, you have become well; do } \\
\text { not sin anymore, so that nothing worse happens } \\
\text { to you." The man went away, and told the Jews } \\
\text { that it was Jesus who had made him well. }\end{array}$ \\
\hline $\begin{array}{l}\text { A second time they called the man who had } \\
\text { been blind, and said to him, "Give glory to } \\
\text { God; we know that this man is a sinner." }\end{array}$ & $\begin{array}{l}\text { For this reason the Jews were persecuting } \\
\text { Jesus, because He was doing these things on the } \\
\text { Sabbath. }\end{array}$ \\
\hline \multirow[t]{2}{*}{$\begin{array}{l}\text { The man said, "Whether He is a sinner, I do } \\
\text { not know; one thing I do know, that though I } \\
\text { was blind, now I see." } \\
\text { So they said to him, "What did He do to you? } \\
\text { How did He open your eyes?" } \\
\text { The man answered, "I told you already and } \\
\text { you did not listen; why do you want to } \\
\text { hear it again? You do not want to become His } \\
\text { disciples too, do you?" }\end{array}$} & \\
\hline & $\begin{array}{l}\text { But Jesus answered them, "My Father is } \\
\text { working until now, and I Myself am working." }\end{array}$ \\
\hline
\end{tabular}

Table 2

Another interesting point to note is that the pool of Siloam was located at the bottom of the Kidron Valley. The water was supplied into the pool through Hezekiah's tunnel from the spring of Gihon, which was located near the temple where the blind man was situated at the beginning of John $9 .{ }^{27}$ Therefore, the man would have had to travel all the way down the hill and find the pool of Siloam ${ }^{28}$ blindly in order to be healed by a man whom he could not even see. The key point is that the man heard Jesus' voice and had faith in His guidance. The lame man,

${ }^{27}$ Edward M. Blaiklock, R. K. Harrison, and David R. Douglass, eds., The New International Dictionary of Biblical Archeology (Grand Rapids, MI: Zondervan Publishing House), 414.

${ }^{28}$ Please refer to Appendix B for a visual illustration of the distance from the Jerusalem temple to the pool of Siloam. Shiloah (Siloam) Pool. Accessed April 1, 2019. https://biblewalks.com/sites/ShiloahPool.html. 
contrastingly, did not have to travel anywhere in order to be healed. His task was to be able to spiritually see that Jesus was the true prophet of God, and the Messiah. The word prophet was also mentioned in John 4, when the Samaritan woman realized that Jesus knew everything about her situation, and was later echoed in John 9. Both the Woman at the Well and the formerly blind man were able to see that Jesus was more than just a mere man and recognized Him for it. The formerly lame man did not recognize this, but instead decided to focus on relieving himself of any trouble with the Pharisees for carrying his mat on the Sabbath. The lame man could have been a witness for Jesus but he decided to appease the questionings of the Jewish leaders instead.

As a result of the blind man's testimony of Jesus' identity and his ardent proclamation of Him as a prophet of God, the man's neighbors began asking, "How can a man who is a sinner perform such signs?" (NASB). This led to division amongst the Jews, which implies that some of the people present had begun to believe that Jesus was more than just a sinner and a man. People with disabilities may also be an extension of Jesus' work while it is day. Many hearts can be reached by being a witness for Christ in the face of skeptical and unwilling neighbors. Instead of focusing on surviving the social backlash of their condition, people with physical infirmities are also able to shed light on God's glory through the way that He is able to work in their lives.

\section{Conclusion}

God does not utilize physical incapacities as a means to strong-arm the stray sheep back into the fold. Genesis 32 and Acts 9 demonstrate that God's touch had a specific role in transforming and reframing Jacob and Saul's outlook on their current position in life. Jacob was overwhelmed with guilt and fear, and Saul was blinded by misguided zeal prior to both of their theophanies. The Divine allowed the men to experience their disabilities so that He could rebuild their understanding of who is in their lives. For Jacob, it was to shift from a passive relationship 
with God to an empowered understanding of His constant forgiveness and presence. Jacob no longer had to torment himself about whether or not God would deliver him. The limp of his thigh represented a permanent embodiment of his conversion, and the shift in his foundation as a person. For Saul, the blindness served to spark his baptism by fire. Saul's loss of sight not only allowed him to open his vision by hearing Jesus' voice, but it also presented a corrector to overemphasized importance of sight that saturated the minds of his fellow Greeks. The Father did not intend to use human wounds to solicit human trust; he desired to transform the biblical figures through necessary events. Furthermore, the appearance of disabilities may also be utilized to influence a larger audience beyond the affected individual. John 9 demonstrates how physical blindness in one person, and their response of faith can draw the attention of the surrounding people to their own spiritual blindness.

In regards to the earlier postulations of Basselin, I would have to disagree with his assertion that disabilities are conditions that allow people to more perfectly reflect the un-whole human nature. I agree that disabilities are able to benefit a person's theology by realizing their shortcomings, but the subtle difference is that God does not intend to make people un-whole. Contrariwise, the Divine Creator desires to restore the tattered edges of the affected individual's faith, or to mend the cognitive discord of the people that surround them, which is the opposite of becoming more un-whole. The strengthening of human faith was not meant to be a byproduct of being less than perfect with the appearance of a disability, but the consequence of realizing a person's profound heart condition. The disability, although adverse in physical terms as a result of the condition of sin rather than the act of it, is allowed to occur by God in order that the specific condition may remedy the specific spiritual lacking. Therefore, people with physical 
incapacities should not be treated as imperfect beings that have fallen below the threshold of normalcy. 


\section{BIBLIOGRAPHY}

Andrews Study Bible: Light. Depth. Truth. Berrien Springs, MI: Andrews University Press, 2010.

Angel, Hayyim. "Sarah's Treatment of Hagar (Genesis 16): Morals, Messages, And Mesopotamia." Jewish Bible Quarterly41, No. 4 (2013). Http://Jbqnew.Jewishbible.Org/Assets/Uploads/414/Jbq_414_1_Angelhagar.Pdf.

Basselin, Tim. "Why Theology Needs Disability." Theology Today68, no. 1 (2011): 47-57. doi:10.1177/0040573610394925.

Blaiklock, Edward M., R. K. Harrison, and David R. Douglass, eds. The New International Dictionary of Biblical Archeology. Grand Rapids, MI: Zondervan Publishing House.

Botterweck, Gerhard Johannes, Helmer Ringgren, and John Thomas Willis. Theological Dictionary of the Old Testament. Grand Rapids, MI: W.B. Eerdmans, 1974.

Carlson, Mary. "Making the Invisible Visible: Inviting Persons with Disabilities into the Life of the Church." Horizons 45, no. 01 (2018): 46-73. doi:10.1017/hor.2018.52.

Cross, Richard. "Duns Scotus on Disability: Teleology, Divine Willing, and Pure Nature." Theological Studies 78, no. 1 (2017): 72-95. doi:10.1177/0040563916682324.

Cunningham, Valentine. "'It Is No Sin To Limp'." Literature and Theology 6, no. 4 (December 1992): 303-09. doi:10.1093/litthe/6.4.303.

Drench, Meredith E., Ann C. Noonan, Nancy Sharby, and Susan H. Ventura. Psychosocial Aspects of Health Care. 3rd ed. Upper Saddle River, NJ, NJ: Pearson, 2012.

"Exodus 3:1 (LXX)." Blue Letter Bible. Accessed March 16, 2019. https://www.blueletterbible.org/lxx/exo/3/1/s_53001.

George, Samuel. "God of Life, Justice and Peace." The Ecumenical Review64, no. 4 (2012): 45462. doi:10.1111/erev.12003.

Harris, R. Laird, Gleason Leonard Archer, and Bruce K. Waltke. Theological Wordbook of the Old Testament. 2 vols. Chicago: Moody Press, 1980.

Hefner, Philip. "Mobility: Disability and Life in the Spirit." Dialog51, no. 3 (2012): 195-201. doi:10.1111/j.1540-6385.2012.00685.x.

http://web.b.ebscohost.com/ehost/pdfviewer/pdfviewer?vid=0\&sid=f5f00c07-04b5-4b78-a5ad13 c657535388\%40sessionmgr101.

Kittel, Gerhard, Gerhard Friedrich, and Geoffrey William Bromiley. Theological Dictionary of the New Testament. Grand Rapids, MI: Eerdmans, 2006. 
Moede, Gerald. "Gods Power and Human Ability." The Ecumenical Review36, no. 3 (1984): 290-98. doi:10.1111/j.1758-6623.1984.tb03650.x.

Schaab, Gloria L. "Disabling Christian Discourse the Mystery of God in the Experience of Disability," Theoforum 46, no. 2 (2015): 219-40. doi:10.2143/tf.46.2.3209417.

Scott, Mark S M. "Suffering and Soul-Making: Rethinking John Hick's Theodicy." The Journal of Religion 90, no. 3 (July 2010): 313-34.

Shiloah (Siloam) Pool. Accessed April 1, 2019. https://biblewalks.com/sites/ShiloahPool.html.

Strong's Greek: 5185. Tvp入ós (Tuphlos) -- Blind. Accessed March 14, 2019. https://biblehub.com/greek/5185.htm.

Swinton, John. "Who Is the God We Worship? Theologies of Disability; Challenges and New Possibilities." International Journal of Practical Theology14, no. 2 (2011). doi:10.1515/ijpt.2011.020.

US Census Bureau Public Information Office. "Nearly 1 in 5 People Have a Disability in the U.S., Census Bureau Reports." U.S. Census Bureau. May 19, 2016. Accessed February 12, 2019. https://www.census.gov/newsroom/releases/archives/miscellaneous/cb12134.html. 


\section{APPENDIX A}

\begin{tabular}{|c|c|}
\hline Jacob's Thigh - ișㄱ? (yə·rê·kōw) & Paul's Sight - ̌ै $\beta \lambda \varepsilon \pi \varepsilon v$ (eblepen) \\
\hline $\begin{array}{l}\text { In the time of the Patriarchs, the thigh was } \\
\text { closely associated to manhood, and the } \\
\text { foundation upon which a person orients their life. }\end{array}$ & $\begin{array}{l}\text { It signified a stronger emphasis on the } \\
\text { function of the eye than in óó } \omega \text { and } \\
\theta \varepsilon \omega \rho \varepsilon \dot{\varepsilon} \omega \text {, but they can be used } \\
\text { interchangeably. Oftentimes, the } \\
\text { combination of seeing and hearing connote } \\
\text { the completeness of spiritual perception. } \\
\text { The Greeks were "a people of the eye," and } \\
\text { considered the ability to see as a crucial } \\
\text { part of regular life and religion. }\end{array}$ \\
\hline $\begin{array}{l}\text { Genesis } 24: 9 \text { - Eliezer "placed his hand under the } \\
\text { thigh of Abraham, his master, and swore to him } \\
\text { concerning" his promise to find Isaac a spouse. } \\
\text { Jud } 3: 16 \text { - Ehud "girded his sword on his right } \\
\text { thigh." } \\
\text { Ephesians } 6: 14-\text { "...having girded your loins } \\
\text { with truth...". }\end{array}$ & $\begin{array}{l}\text { Matthew } 12: 38 \text { - The scribes and Pharisees } \\
\text { asked, "to see a sign." } \\
\text { John 11:45 - Mary, "having seen what He } \\
\text { did, believed in Him." } \\
\text { John 4:48 - "Unless you people see signs } \\
\text { and wonders... you will never believe." }\end{array}$ \\
\hline $\begin{array}{l}\text { The displacement of Jacob's thigh signified a } \\
\text { shift in Jacob's identity and personhood. }\end{array}$ & $\begin{array}{l}\text { Paul's temporary loss of sight exposed his } \\
\text { need to hear God's voice rather than to } \\
\text { simply march forward with misplaced } \\
\text { confidence in what the future apostle saw } \\
\text { as right. }\end{array}$ \\
\hline
\end{tabular}




\section{APPENDIX B}

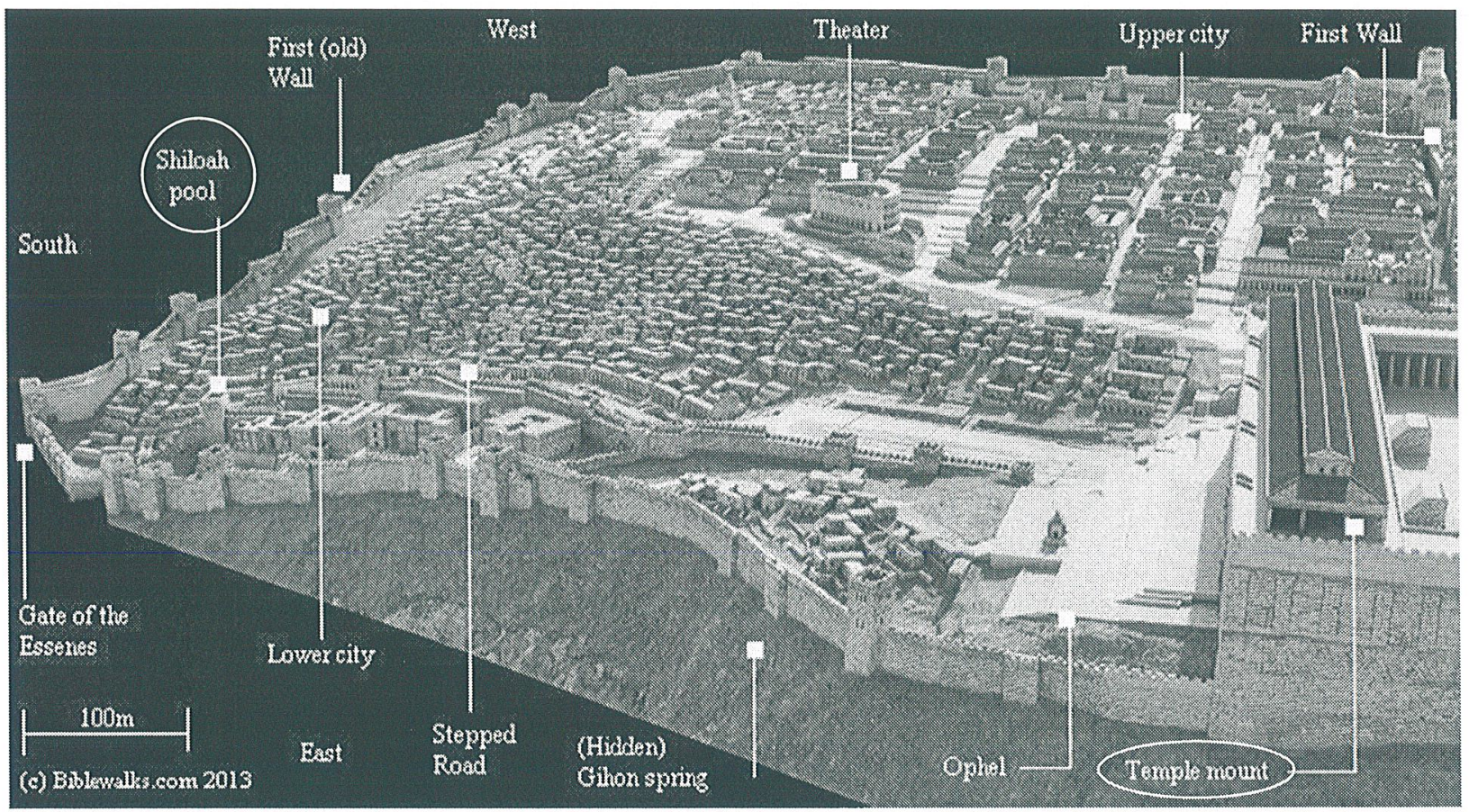

Image was taken from Shiloah (Siloam) Pool. Accessed April 1, 2019. https://biblewalks.com/sites/ShiloahPool.html. 